\title{
PERSANDINGAN LEMBAGA OMBUDSMAN DAERAH ISTIMEWA YOGYAKARTA DENGAN OMBUDSMAN PERWAKILAN DAERAH PROVINSI
}

\author{
Noviana \\ Magister Ilmu Hukum, Fakultas Hukum, Universitas Airlangga \\ e-mail: noviana-2019@fh.unair.ac.id
}

\begin{abstract}
ABSTRAK
Provinsi Daerah Istimewa Yogyakarta memiliki dua lembaga pengawasan penyelenggaraan pelayanan publik yaitu Lembaga Ombudsman Daerah Istimewa Yogyakarta dan Ombudsman Perwakilan Daerah Provinsi sehingga perlu dikaji mengenai kedudukan hukum Lembaga Ombudsman Daerah Istimewa Yogyakarta dalam sistem otonomi daerah dan hubungannya dengan kedudukan Ombudsman Perwakilan Daerah Provinsi agar tidak terjadi pertentangan. Penelitian hukum normatif ini menggunakan metode pendekatan statute approach dan case approach. Hasil penelitian menunjukan bahwa Lembaga Ombudsman Daerah Istimewa Yogyakarta merupakan lembaga independen daerah sebagai salah satu wujud pengejawantahan asas desentralisasi dalam menyelenggarakan pemerintahan daerah pada kerangka otonomi daerah sedangkan Lembaga Ombudsman Daerah Istimewa Yogyakarta memiliki hubungan fungsional dengan Ombudsman Perwakilan Daerah Provinsi. Lembaga Ombudsman Daerah Istimewa Yogyakarta berbeda dengan Ombudsman Perwakilan Daerah Provinsi namun pengaturan mengenai lembaga ombudsman nasional, ombudsman perwakilan di daerah dan ombudsman daerah masih tumpang tindih antara satu dengan yang lain serta Undang-Undang Nomor 23 Tahun 2014 belum memberikan pengakuan terhadap lembaga ombudsman yang dibentuk oleh pemerintah daerah.
\end{abstract}

Kata Kunci: Ombudsman; Pelayanan Publik; Pemerintahan Daerah

\section{ABSTRACT}

The Special Region of Yogyakarta has two institutions to supervise the implementation of public services, namely The Special Region of Yogyakarta Ombudsman Institute and the Provincial Representative Ombudsman so that it is necessary to study the legal position of the The Special Region of Yogyakarta Ombudsman Institute in the regional autonomy system and its relationship to the position of the Provincial Representative Ombudsman so that there is no future conflict. This normative legal research uses a statute approach and a case approach. The results showed that The Special Region of Yogyakarta Ombudsman Institute is a regional independent institution as a manifestation of the decentralization principle in administering regional governance in the framework of regional autonomy, while The Special Region of Yogyakarta Ombudsman Institute has a functional relationship with the Provincial Representative Ombudsman. The Special Region of Yogyakarta Ombudsman Institute is still different from the Provincial Representative Ombudsman, but the regulations regarding the national ombudsman, regional representative ombudsman and regional ombudsman still overlap with one another and Law Number 23 of 2014 has not given recognition to the ombudsman institution established by regional government.

Keywords: Ombudsman; Public Service; Local Government 


\section{PENDAHULUAN}

Lord Acton pernah berpendapat bahwa setiap orang yang memiliki kekuasaan cenderung untuk menyalahgunakan kekuasaan itu, oleh karena itu siapapun yang memiliki kekuasaan tak terbatas pasti akan menyalahgunakan kekuasaan tersebut secara tak terbatas pula. ${ }^{1}$ Oleh karenanya, kekuasaan harus dibatasi sehingga dalam hal ini konstitusi berperan sebagai pembatas untuk menghindari adanya penyalahgunaan atau kesewenang-wenangan kekuasaan. Seperti yang dikemukakan oleh Ivo D. Duchaek yang menyatakan bahwa konstitusi bertujuan untuk "identify the sources, purposes, uses and restraints of public power". ${ }^{2}$ Pembatasan kekuasaan tersebut ditujukan agar kekuasaan tidak berubah menjadi absolut dan mudah untuk koruptif. ${ }^{3}$ Selaras dengan hal tersebut dalam konstitusi Indonesia disebutkan bahwa Negara Indonesia adalah negara hukum. Dimana salah satu ciri dari negara hukum yaitu dalam penyelenggaraan kekuasaan negara terdapat pembatasan kekuasaan. ${ }^{4}$

Terkait ajaran mengenai pemisahan kekuasaan, pemikiran yang dianggap paling berpengaruh yaitu pendapat dari Montesquieu tentang teori Trias Politica yang membagi cabang kekuasaan menjadi 3 (tiga) yaitu legislatif, eksekutif atau administratif, dan yudisial. ${ }^{5}$ Namun sesuai dengan perkembangan konsep tersebut sudah tidak lagi relevan, menurut Jimly Asshiddiqie, hubungan antar cabang kekuasaan sudah tidak mungkin lagi untuk tidak saling bersentuhan, ketiganya bersifat sederajat dan bahkan saling mengendalikan satu sama lain sesuai dengan prinsip checks and balances. ${ }^{6} \mathrm{Hal}$ tersebut merupakan konsekuensi yuridis amandemen UndangUndang Dasar 1945 yang menempatkan struktur kelembagaan negara berada pada posisi yang sama/ sejajar sehingga asas struktural hierarkis sudah tidak

1 Zainal Arifin Mochtar. (2019). Lembaga Negara Independen. Depok: Rajawali Pers, h. 12.

${ }^{2}$ Jimly Asshiddiqie. (2017). Konstitusi \& Konstitusionalisme Indonesia. Jakarta: Sinar Grafika, h. 17. (selanjutnya disingkat Jimly Asshiddiqie I).

${ }^{3}$ Zainal Arifin Mochtar. loc.cit.

${ }^{4}$ Jimly Asshiddiqie. (2013). Pengantar Ilmu Hukum Tata Negara. Jakarta: Rajawali Pers, h. 281. (selanjutnya disingkat Jimly Asshiddiqie II).

${ }^{5}$ ibid., h. 282.

${ }^{6}$ Jimly Asshiddiqie. (2016). Perkembangan \& Konsolidasi Lembaga Negara Pasca Reformasi. Jakarta: Sinar Grafika, h. v. (selanjutnya disingkat Jimly Asshiddiqie III). lagi dianut melainkan kini fungsional. ${ }^{7}$ Berkat adanya pergeseran tersebut, maka antar lembaga negara saling terkait satu dengan yang lain dan saling dapat mengontrol sebagai pengejawatan prinsip checks and balances. ${ }^{8}$

Keberadaan lembaga-lembaga negara memang ide awalnya untuk melakukan pembatasan kekuasaan. Disisi lain, perkembangan masyarakat menghendaki adanya struktur organisasi negara yang lebih responsif menanggapai tuntutan masyarakat, serta lebih efisien dan efektif dalam melakukan pelayanan publik serta dalam mencapai tujuan penyelenggaraan pemerintahan. ${ }^{9}$ Selanjutnya sebagai respon negara terhadap permasalahan negara yang semakin hari semakin kompleks, maka lahirlah lembaga-lembaga negara baru yang bersifat independen yang disebut sebagai auxiliary institutions atau state auxiliary organs atau lembaga negara yang bersifat penunjang. Diantara lembaga-lembaga tersebut terkadang ada yang disebut sebagai independent supervisory bodies, self regulatory agencies, atau lembaga-lembaga yang menjalankan fungsi campuran (mix-function) antara fungsi regulatif, administratif dan fungsi penghukuman yang dilakukan secara bersamaan oleh lembaga-lembaga baru tersebut. ${ }^{10}$

Lembaga negara baru yang diadakan oleh konstitusi kita adalah Dewan Perwakilan Daerah, Komisi Yudisial, Mahkamah Konstitusi, Komisi Pemilihan Umum, dan Bank Sentral. Sedangkan keberadaan Dewan Pertimbangan Agung telah digantikan dengan dewan pertimbangan yang dibentuk oleh Presiden. Sedangkan lembaga-lembaga lain yang diluar yang disebutkan oleh UUD 1945 yaitu Komisi Pemberantasan Korupsi, Komisi Perlindungan Anak Indonesia, Ombudsman Republik Indonesia, Komisi Penyiaran Indonesia, dan lain-lain.

Berdasarkan uraian tersebut, menunjukan dengan jelas bahwa lahirnya Ombudsman Republik Indonesia sebagai sarana untuk mewujudkan negara hukum itu sendiri. Philipus M. Hadjon berpendapat mengenai ciri-ciri dari rechtsstaat berdasarkan pandangan dari

${ }^{7}$ H.M. Galang Asmara. (2016). Hukum Kelembagaan Negara: Kedudukan Ombudsman Dalam Sistem Ketatanegaraan Republik Indonesia. Yogyakarta: LaksBang PRESSindo, h. 122.

${ }^{8}$ ibid., h. 126.

${ }^{9}$ Gunawan A. Tauda. (2012). Komisi Negara Independen. Yogyakarta: Genta Press, h. 4.

${ }^{10}$ Jimly Asshiddiqie II. op.cit., h. 338-339. 
S.W. Couwenberg mengenai sifat-sifat liberal dan demokrasi, meliputi: ${ }^{11}$

a. adanya konstitusi atau undang-undang dasar yang mengatur hubungan antara rakyat dan penguasa secara tertulis;

b. adanya pembagian kekuasaan negara yaitu kekuasaan pembuatan undang-undang yang berada pada parlemen, kekuasaan kehakiman yang bebas tidak hanya dalam menangani sengketa antara sesama individu melainkan juga sengketa antara rakyat dan penguasa, dan pemerintah yang segala tindakannya harus didasarkan pada undang-undang (wetmatig bestuur);

c. adanya hak-hak kebebasan rakyat yang diakui dan dilindungi (vrijheidsrechten van de burger).

Sejalan dengan pandangan tersebut, Hirch Ballin, menyatakan pendapatnya mengenai ciri-ciri negara hukum, antara lain yaitu setiap kebijakan pemerintah harus berdasarkan undang-undang, hakhak mengenyam kebebasan harus menghormati oleh Negara, Penguasa harus terikat pada hukum, Mengupayakan terwujudnya keadilan sosial; dan Hukum harus jelas dan stabil. ${ }^{12}$

Berbicara mengenai hak-hak rakyat, memperoleh pelayanan publik yang efektif dan efiesien merupakan hak dasar setiap warga negara. Dalam Pasal 1 angka 1 Undang-Undang Nomor 25 Tahun 2009 tentang Pelayanan Publik (selanjutnya disebut UU No. 25 Tahun 2009), pelayanan publik didefinisikan sebagai kegiatan atau rangkaian kegiatan dalam rangka pemenuhan kebutuhan pelayanan sesuai dengan peraturan perundang-undangan bagi setiap warga negara dan penduduk atas barang, jasa dan/ atau pelayanan administrasi yang disediakan oleh penyelenggara pelayanan publik. Secara singkat atau sederhana penyelenggara pelayanan publik adalah pemerintah.

Perlu diingat bahwa, hubungan penguasa dalam hal ini pemerintah dengan rakyat merupakan hubungan yang subordinatif. Kondisi demikian sesuai pendapat P. de Haan Cs. yang mengemukakan tentang tiga fungsi hukum administrasi yaitu norma,

\footnotetext{
${ }^{11}$ Philipus M. Hadjon. (1987). Perlindungan Hukum Bagi Rakyat di Indonesia. Surabaya: Bina Ilmu, h. 76.

${ }^{12}$ Muh. Hasrul. "Penataan Hubungan Kelembagaan Antara Pemerintah Provinsi dengan Pemerintah Kabupaten/Kota". Jurnal PERSPEKTIF. Fakultas Hukum Universitas Wijaya Kusuma Surabaya, Vol. 22 No. 1 Tahun 2017 Edisi Januari, h. 4.
}

instrumen dan jaminan. ${ }^{13}$ Dimana dideskripsikan bahwa salah satu ruang lingkup hukum administrasi yaitu meliputi sarana penguasa atau pemerintah untuk mengendalikan dan mengatur masyarakat termasuk pula mengatur bagaimana cara-cara partisipasi warga negara dalam proses pengaturan dan pengendalian oleh penguasa atau pemerintah tersebut, namun oleh karena hubungan antara penguasa dan masyarakat yang nampak jelas subordinatif perlu adanya perlindungan hukum (rechtsbescherming) bagi masyarakat agar penguasa tidak sewenangwenang atau menyalahgunakan kewenangan, dan menetapkan fundamental norms bagi penguasa untuk pemerintahan yang baik (algemene beginselen van behoorlijk bestuur). ${ }^{14}$

Hubungan subordinatif yang terjalin antara pemerintah dengan rakyat membuat perlunya perlindungan hukum bagi rakyat agar terhindar dari tindakan buruk penguasa dalam penyelenggaraan pelayanan publik. Untuk itu, dibentuklah lembaga ombudsman yang mengikuti perkembangan negara-negara maju seperti Swedia, Finlandia, Denmark, New Zealand, Norwegia dan disusul oleh negara-negara lain hingga Belanda dimana negaranegara tersebut seolah-olah saling berlomba untuk membentuk lembaga ombudsman. ${ }^{15}$

Lembaga Ombudsman merupakan sarana membatasi dan mengontrol kekuasaan agar tidak disalahgunakan, sehingga tidak terjadi kekuasaan yang sewenang-wenang (absolut). ${ }^{16}$ Keberadaan lembaga ombudsman erat kaitannya dengan pendekatan fungsionaris dalam hukum administrasi.Pendekatan fungsionaris fokus pada aparat pemerintah dalam menjalankan fungsinya. ${ }^{17}$ Pendekatan fungsionaris berbicara mengenai maladministrasi yang menyoroti perilaku (behaviour) dari aparat dalam melaksanakan tugas pemerintahan, maupun dalam kaitan tugas

\footnotetext{
${ }^{13}$ Philipus M. Hadjon, et.al. (2015). Pengantar Hukum Administrasi Indonesia. Yogyakarta: Gadjah Mada University Press, h. 28. (selanjutnya disingkat Philipus M. Hadjon, et.al.).

${ }^{14}$ ibid.

${ }^{15}$ H.M. Galang Asmara. op.cit., h. 8.

${ }^{16}$ ibid., h. 42.

${ }^{17}$ Tatiek Sri Djatmiati. (2020). Faute Personelle dan Faute De Service Dalam Tanggung Gugat Negara, dalam Hukum Administrasi Sebuah Bunga Rampai. Yogyakarta: LaksBang Justitia, h. 5. (selanjutnya disingkat Tatiek Sri Djatmiati I).
} 
pelayanan publik, ${ }^{18}$ jadi titik beratnya adalah pada pengawasan perilaku aparat (overheidsgedrag). ${ }^{19}$

Dalam Pasal 1 angka 3 Undang-Undang Nomor 37 Tahun 2008 tentang Ombudsman Republik Indonesia (selanjutnya disebut dengan UU No. 37 Tahun 2008), maladministrasi didefinisikan sebagai perilaku atau perbuatan melawan hukum, melampaui wewenang, menggunakan wewenang untuk tujuan lain dari yang menjadi tujuan wewenang tersebut, termasuk kelalaian atau pengabaian kewajiban hukum dalam penyelenggaraan pelayanan publik yang dilakukan oleh penyelenggara negara dan pemerintahan yang menimbulkan kerugian materiil dan/atau immaterial bagi masyarakat dan orang perseorangan. Sehingga nampak bahwa maladministrasi merupakan suatu tindakan atau perilaku yang menyimpang dari etika administrasi atau suatu perbuatan administrasi yang menjauhkan dari pencapaian tujuan administrasi. ${ }^{20}$ Sehingga di Belanda dalam melakukan pengawasan terhadap perilaku aparat harus mengindahkan normanorma umum perilaku yang baik (algemene normen van goed overheidsgedrag) atau beginselen van behoorlijk overheidsgedrag sebagai acuannya. ${ }^{21}$ Terkait dengan hal tersebut Indonesia menganut hal yang sama sebab Indonesia menerapkan asas konkordansi dari Belanda.

Ombudsman di Indonesia sebelumnya diberi nama Komisi Ombudsman Nasional yang dibentuk berdasarkan Keputusan Presiden Nomor 44 Tahun 2000 tentang Komisi Ombudsman Nasional. Pada tahun 2008 sejak diundangkan Undang-Undang Nomor 37 Tahun 2008 tentang Ombudsman Republik Indonesia maka Komisi Ombudsman Nasional beralih menjadi Ombudsman Republik Indonesia. Ombudsman Republik Indonesia merupakan lembaga pengawasan yang bersifat eksternal, ${ }^{22}$ yang berkedudukan di Ibu Kota Negara Republik

${ }^{18}$ Tatiek Sri Djatmiati. (2010). Maladministrasi Dalam Konteks Kesalahan Pribadi dan Kesalahan Jabatan, Tanggung Jawab Pribadi dan Tanggung Jawab Jabatan, dalam Philipus M. Hadjon, et.al. Hukum Administrasi dan Good Governance. Jakarta: Penerbit Universitas Trisakti, h. 76. (selanjutnya disingkat Tatiek Sri Djatmiati II).

19 ibid., h. 85.

20 Nuryanto A. Daim. (2014). Hukum Administrasi Perbandingan Penyelesaian Maladministrasi oleh Ombudsman dan Pengadilan Tata Usaha Negara. Surabaya: LaksBang Justitia, h. 58.

${ }^{21}$ Tatiek Sri Djatmiati II. op.cit., h. 85.

${ }^{22}$ H.M. Galang Asmara. op.cit., h. 140.
Indonesia dengan yuridiksi meliputi seluruh wilayah Negara Kesatuan Republik Indonesia.

Wilayah Negara Kesatuan Republik Indonesia (NKRI) sangat luas dengan masyarakatnya yang beraneka ragam. Apabila semua itu mengandalkan pemerintah pusat untuk mengatasi permasalahanpermasalahan terkait pelayanan publik di daerah tentunya membutuhkan waktu yang lama, sehingga dalam Pasal 43 UU No. 37 Tahun 2008, disebutkan bahwa manakala dipandang perlu maka Ombudsman Republik Indonesia dapat mendirikan perwakilan Ombudsman di daerah provinsi atau kabupaten/kota. Dimana perwakilan ombudsman di daerah tersebut memiliki hubungan hierarkis dengan Ombudsman Republik Indonesia.

Pemerintah daerah memiliki kewenangan untuk mengurus sendiri urusan pemerintahan menurut asas otonomi dan tugas pembantuan. Secara tersirat dalam Pasal 18A ayat (1) dan Pasal 18B ayat (1) UUD 1945, tiap-tiap daerah di Indonesia memiliki kekhususan dan keragaman daerah sehingga setiap daerah di Negara Republik Indonesia memiliki karakterisitik yang beraneka ragam. Oleh sebab itu, perlu adanya lembaga Ombudsman yang menguasai dan memahami wawasan Nasional sekaligus karakteristik daerah.

Yogyakarta merupakan salah satu contoh daerah yang memiliki keistimewaan sebagaimana diatur dalam Undang-Undang Nomor 13 Tahun 2012 tentang Keistimewaan Daerah Istimewa Yogyakarta (selanjutnya disebut UU No. 13 Tahun 2012). Salah satu kewenangan istimewa yang dimiliki Daerah Istimewa Yogyakarta sebagai daerah otonom diatur dalam Pasal 7 UU No. 13 Tahun 2012 adalah kewenangan pembentukan kelembagaan Pemerintah Daerah DIY. Kewenangan istimewa tersebut, diselenggarakan untuk mencapai efektivitas serta efisiensi penyelenggaraan pemerintahan dan pelayanan masyarakat berdasarkan prinsip responsibilitas, akuntabilitas, transparansi, dan partisipasi dengan memperhatikan bentuk dan susunan pemerintahan asli sebagaimana diatur dalam Pasal 30 ayat (1) UU No. 13 Tahun 2012. Sehingga sebagai kontrol penyelenggaraan pelayanan publik di Yogyakarta, pemerintahan daerah membentuk suatu lembaga daerah independen untuk mengawasi khususnya penyelenggaraan pelayanan publik yang dilakukan oleh pemerintah daerah dan badan 
usaha yang disebut dengan Lembaga Ombudsman Daerah Istimewa Yogyakarta (selanjutnya disingkat LO DIY). LO DIY memiliki kesamaan fungsi dengan Ombudsman Republik Indonesia maupun ombudsman perwakilan di daerah yaitu melakukan pengawasan terhadap penyelenggaraan pelayanan publik.

Di Provinsi Daerah Istimewa Yogyakarta itu sendiri selain terdapat Lembaga Ombudsman Daerah Istimewa Yogyakarta juga terdapat Ombudsman Perwakilan di Yogyakarta sebagai wakil dari Ombudsman Republik Indonesia. Hal ini menarik untuk diteliti. Pada penelitian yang telah ada terdahulu membahas mengenai LO DIY pasca lahirnya Undang-Undang Nomor 23 Tahun 2014 tentang Pemerintahan Daerah. Salah satu kesimpulan yang didapat dalam penelitian tersebut menunjukan bahwa kedudukan lembaga ombudsman daerah pasca lahirnya Undang-Undang Nomor 23 Tahun 2014 tidak memiliki kepastian hukum karena Undang-Undang Nomor 23 Tahun 2014 tidak mengakomodir Lembaga Ombudsman Daerah, karena bisa ditafsirkan bahwa undang-undang tersebut hanya mengakui "ombudsman" sebagaimana dimaksud dalam Undang-Undang Nomor 37 Tahun 2008 tentang Ombudsman Republik Indonesia. ${ }^{23}$

Terhadap kesimpulan tersebut, Penulis kurang sependapat sebab memang benar jika dilihat berdasarkan bunyi norma dalam Undang-Undang Nomor 23 Tahun 2014 tentang Pemerintahan Daerah seolah hanya mengakui keberadaan "ombudsman" sebagaimana dimaksud dalam Undang-Undang Nomor 37 Tahun 2008. Hal tersebut seolah menunjukan kedudukan ombudsman daerah tidak memiliki kepastian hukum. Namun perlu kita ingat bahwa mempelajari hukum tidak serta merta dari apa yang terlihat. Sehingga perlu dilakukan penelitian ini untuk mengetahui kedudukan LO DIY dalam sistem pemerintahan daerah dan hubungannya dengan Ombudsman Perwakilan di Yogyakarta sebagai wakil dari Ombudsman Republik Indonesia.

\footnotetext{
${ }^{23}$ Dhenok Panuntun Trisuci Asmawati. (2015). "Kedudukan Lembaga Ombudsman Daerah Istimewa Yogyakarta Pasca Undang-Undang Nomor 23 Tahun 2014 tentang Pemerintahan Daerah". hesis. Fakultas Hukum Universitas Islam Indonesia, h. 134. doi: https://dspace.uii.ac.id/bitstream/ handle/123456789/8995/TESIS_Dhenok\%20P.T.A_11912665. pdf? sequence $=1 \&$ isAllowed $=\mathrm{y}$
}

\section{PERUMUSAN MASALAH}

Beranjak dari latar belakang di atas, maka permasalahan yang akan dikaji oleh penulis dalam penelitian ini adalah:

a. Bagaimana kedudukan Ombudsman Daerah Istimewa Yogyakarta dalam sistem pemerintahan daerah?

b. Apa hubungan antara Lembaga Ombudsman Daerah Istimewa Yogyakarta dengan Ombudsman perwakilan di daerah?

\section{METODE PENELITIAN}

Penelitian ini merupakan penelitian hukum karena dalam penelitian ini akan meneliti peraturan perundang-undangan maupun norma hukum. Dan dalam penulisan penelitian ini dilakukan untuk memberikan pemecahan masalah atas masalah hukum yang ada. Dimana yang menjadi fokus dalam penelitian ini berkaitan dengan kedudukan dan yuridiksi Ombudsman di Daerah, Perbandingan Lembaga Ombudsman Nasional, Ombudsman Perwakilan di Daerah dan Ombudsman Daerah Istimewa Yogyakarta untuk selanjutnya diharapkan dapat menentukan bagaimana hubungan Lembaga Ombudsman Nasional dengan Ombudsman Daerah.

Penelitian hukum ini penulis menggunakan statute approach atau yang sering diartikan sebagai pendekatan perundang-undangan. Statute Approach itu sendiri secara singkat merupakan pendekatan dengan menggunakan legislasi dan regulasi. ${ }^{24}$ Peraturan perundang-undangan yang berlaku menjadi fokus utama dari pendekatan ini,tidak hanya dari segi bentuknya saja yang akan ditelaah melainkan juga pada materi muatannya. Tidak berhenti disitu saja, landasan filososi undang-undang, alasan lahirnya undang-undang, dan ratio legis dari suatu ketentuan undang-undang juga sangat penting untuk ditelaah. ${ }^{25}$ Dan untuk selanjutnya, penggunaan pendekatan ini menjadi salah satu bentuk upaya penulis untuk menganalisis konsistensi, hierarki serta kesesuaian antara peraturan perundang-undangan yang ada.

Pendekatan lainnya yang digunakan penulis yaitu case approach. Case approach merujuk pada ratio decidenci. Sehingga dalam menggunakan pendekatan kasus ini, penulis akan memahami ratio decidenci,

\footnotetext{
24 Peter Mahmud Marzuki. (2016). Penelitian Hukum. Jakarta: Prenadamedia Group, h. 137.

${ }^{25}$ ibid., h. 142.
} 
yaitu pertimbangan hukum yang digunakan oleh hakim untuk sampai kepada putusannya. ${ }^{26}$ Dengan menggunakan pendekatan ini, penulis akan memahami ratio decidenci dari Putusan Mahkamah Konstitusi Nomor 62/PUU-VIII/2010 yang membahas mengenai pembentukan ombudsman daerah dan Putusan Mahkamah Konstitusi Nomor 36/PUU-XV/2017 yang membahas mengenai independensi Komisi Pemberantasan Korupsi sebagai lembaga penunjang. Dengan memahami ratio decidenci kedua putusan Mahkamah Konstitusi tersebut, terutama diharapkan dapat membantu penulis untuk menganalisis dan mengkaji terkait dengan permasalahan hukum yang menjadi fokus pembahasan untuk dapat mengetahui pertanggungjawaban dan pengawasan Ombudsman Republik Indonesia untuk dibandingkan dengan pertanggungjawaban dan pengawasan pada LO DIY. Sehingga dapat diketahui hubungan di antara lembaga tersebut.

\section{PEMBAHASAN}

\section{Kedudukan LO DIY Dalam Sistem Pemerintahan Daerah}

Dalam konstitusi kita telah disebutkan bahwa negara Indonesia merupakan negara kesatuan yang berbentuk republik. Berdasarkan susunan negara, Abu Daud Busroh menjelaskan bahwa yang dimaksud negara kesatuan berbeda dengan konsep negara federasi yang tersusun dari beberapa negara, melainkan negara kesatuan itu bersifat tunggal, yang artinya hanya ada satu negara dan tidak ada negara di dalam negara. ${ }^{27}$

Berdasarkan amanat konstitusi, dengan memperhatikan keragaman dan kekhususan daerah, hubungan wewenang antara pemerintah pusat dan daerah atau antar pemerintah daerah akan diatur dalam undang-undang. Untuk itu, menjadi suatu kewajiban negara yang diamanatkan pula oleh konstitusi dimana negara mengakui dan menghormati suatu pemerintahan daerah yang bersifat khusus atau istimewa melalui undang-undang tersendiri. Sebagai wujud pengakuan dan penghormatan negara terhadap keistimewaan daerah Yogyakarta maka diundangkanlah Undang-Undang Nomor 3

\footnotetext{
${ }^{26}$ ibid., h. 158.

${ }^{27}$ Sri Winarsi dan Wilda Prihatiningtyas. (2019). Buku Ajar Pemerintahan Daerah. Surabaya: Airlangga University Press, h. 137.
}

Tahun 1950 tentang Pembentukan Daerah Istimewa Jogjakarta sebagaimana telah diubah beberapa kali terakhir dengan Undang-Undang Nomor 9 Tahun 1955 tentang Pengubahan Undang-Undang No. 3 jo. No. 19 Tahun 1950 tentang Pembentukan Daerah Istimewa Yogyakarta dan pada tahun 2012 lahirlah Undang-Undang Nomor 13 Tahun 2012 tentang Keistimewaan Daerah Istimewa Yogyakarta (selanjutnya disebut UU No. 13 Tahun 2012).

Negara Indonesia sebagai negara kesatuan dalam penyelenggaraan pemerintahan menganut asas desentralisasi dengan memberikan kesempatan dan kekuasaan kepada daerah untuk menyelenggarakan otonomi daerah. ${ }^{28}$ Desentralisasi dapat dibedakan menjadi desentralisasi teritorial dan desentralisasi fungsional. Desentralisasi teritorial melahirkan pemerintahan daerah yang otonom, sedangkan desentralisasi fungsional melahirkan daerah yang melaksanakan fungsi pemerintah pusat di daerah dengan tanggung jawabnya pada pemerintah daerah. ${ }^{29}$

LO DIY diatur dalam Peraturan Gubernur Daerah Istimewa Yogyakarta Nomor 69 Tahun 2014 tentang Organisasi dan Tata Kerja Lembaga Ombudsman Daerah Istimewa Yogyakarta sebagaimana telah diubah berdasarkan Peraturan Gubernur Daerah Istimewa Yogyakarta Nomor 28 Tahun 2019 tentang Perubahan Atas Peraturan Gubernur Daerah Istimewa Yogyakarta Nomor 69 Tahun 2014 tentang Organisasi dan Tata Kerja Lembaga Ombudsman Daerah Istimewa Yogyakarta (selanjutnya disebut Pergub DIY No. 69 Tahun 2014 jo. Pergub DIY No. 28 Tahun 2019). Dalam Peraturan Gubernur tersebut disebutkan bahwa LO DIY merupakan lembaga daerah yang bersifat independen untuk mengawasi penyelenggaraan pemerintah daerah dan badan usaha, khususnya pada bidang pelayanan publik. LO DIY merupakan penggabungan dari Ombudsman Daerah di Provinsi Daerah Istimewa Yogyakarta (selanjutnya disebut Ombudsman Daerah DIY) dan Ombudsman Swasta di Provinsi Daerah Istimewa Yogyakarta (selanjutnya disebut Ombudsman Swasta DIY). Penggabungan Ombudsman Daerah DIY dengan Ombudsman Swasta DIY menjadi LO DIY dilakukan

\footnotetext{
${ }^{28}$ Sri Winarsi. (2018). Kedudukan Badan Pertanahan Nasional di Era Otonomi Daerah. Surabaya: Airlangga University Press, h. 21.

${ }^{29}$ ibid., h. 22.
} 
dengan tujuan untuk lebih dapat berdaya guna dan berhasil guna.

Salah satu hal yang menarik dalam Pergub DIY No. 69 Tahun 2014 jo. Pergub DIY No. 28 Tahun 2019 adalah pada bagian mengingat, yang berisi dasar hukum sebagai dasar kewenangan pembuatan Peraturan Perundang-undangan dan Peraturan PerundanguUndangan apa saja yang memerintahkan pembuatan Peraturan PerundangUndangan tersebut. ${ }^{30}$ Dalam bagian mengingat peraturan gubernur tersebut, selain mencantumkan Undang-Undang Nomor 23 Tahun 2014 tentang Pemerintahan Daerah (selanjutnya disebut UU No. 23 Tahun 2014), juga mencantumkan UU No. 13 Tahun 2012. Sehingga menimbulkan tanya apakah keberadaan LO DIY merupakan salah satu wujud kewenangan istimewa yang diberikan oleh UU No. 13 Tahun 2012.

Kewenangan istimewa DIY diatur dalam UU No. 13 Tahun 2012, sehingga Pemerintah Daerah Istimewa mempunyai kewenangan yang meliputi kewenangan istimewa berdasarkan UndangUndang ini dan kewenangan berdasarkan undangundang tentang pemerintahan daerah. ${ }^{31}$ Salah satu kewenangan istimewa DIY berkaitan dengan pembentukan kelembagaan Pemda DIY. Ketentuan mengenai penataan dan penetapan kelembagaan Pemerintah Daerah DIY sebagaimana dimaksud pada ayat (1) diatur dalam Perda Istimewa.

Saat ini kelembagaan Pemda DIY diatur dalam Perdais DIY Nomor 1 Tahun 2018 tentang Kelembagaan Pemerintah Daerah Daerah Istimewa Yogyakarta (selanjutnya disebut Perdais No. 1 Tahun 2018). Dalam Perdais No. 1 Tahun 2018 tidak disebutkan bahwa LO DIY merupakan lembaga yang dibentuk berdasarkan kewenangan istimewa yang diperoleh dari UU No. 13 Tahun 2012. Perangkat daerah yang diatur dalam Perdais No. 1 Tahun 2018 dibentuk berdasarkan karakteristik, beban kerja, dan tata kerja keistimewaan yang disinkronkan dengan visi, misi, dan program kerja pembangunan daerah meliputi Sekretariat Daerah, Paniradya Kaistimewan, Sekretariat DPRD, Inspektorat, Dinas Daerah, Badan Daerah dan Badan Penghubung

30 Maria Farida Indrati S. (2016). Ilmu Peraturan Perundang-Undangan 2 Proses dan Teknik Pembentukannya. Yogyakarta: Kanisius, h. 110.

${ }^{31}$ Sri Winarsi dan Wilda Prihatiningtyas. op.cit., h. 163.
Daerah. Oleh karenanya pembentukan LO DIY murni merupakan wujud kemandirian dan inovasi daerah dalam penerapan asas desentralisasi dalam menyelenggarakan pemerintahan daerah.

Pasal 351 ayat (1) UU No. 23 Tahun 2014 menyebutkan bahwa masyarakat mempunyai hak untuk mengadukan penyelenggaraan pelayanan publik kepada Pemerintah Daerah, Ombudsman dan/atau DPRD. Ombudsman yang dimaksud dalam Pasal 351 ayat (1) UU No. 23 Tahun 2014 dalam penjelasan pasal adalah Ombudsman Republik Indonesia yang diatur dalam UU No. 37 Tahun 2008. Berdasarkan ketentuan pasal tersebut seolah UU No. 23 Tahun 2014 hanya mengakui ombudsman yang dibentuk berdasarkan UU Ombudsman Republik Indonesia. Perlu diingat bahwa selain pada Ombudsman Republik Indonesia, masyarakat juga dapat mengadukan penyelenggaraan pelayanan publik pada Pemerintah Daerah. Definisi mengenai pemerintah daerah dan pemerintahan daerah dapat kita temui dalam UU No. 23 Tahun 2014. Dimana dari definisi pemerintahan daerah dan pemerintah daerah yang terkandung dalam UU No. 23 Tahun 2014 dapat kita simpulkan bahwa pemerintahan daerah merujuk pada fungsi sedangkan pemerintah daerah merujuk pada organ.

Berdasarkan Pasal 344 UU No. 23 Tahun 2014, lahirlah kewajiban undang-undang dimana Pemerintah Dearah sebagai suatu organ wajib untuk menjamin terselenggaranya pelayanan publik berdasarkan urusan pemerintahan yang menjadi kewenangannya.Untuk itu pemerintah daerah DIY membentuk LO DIY untuk menjamin pemberian pelayanan kepada masyarakat sehingga perlu adanya pengawasan terhadap penyelenggaraan pelayanan publik.

LO DIY merupakan lembaga daerah independen yang berkedudukan di Daerah Istimewa Yogyakarta untuk melalukan pengawasan penyelenggaraan pemerintah daerah dan badan usaha khususnya pada bidang pelayanan publik yang bertanggungjawab langsung pada Gubernur sebagai kepala daerah DIY. Dalam menjalankan tugas dan fungsinya Lembaga Ombudsman DIY memperoleh sumber keuangan dari APBD DIY dan sumber dana lain yang sah dan tidak mengikat.

LO DIY mempunyai fungsi sebagai lembaga pengawasan, mediasi pelayanan masyarakat terhadap 
penyelenggaraan pemerintahan daerah dan praktik dunia usaha. Keberadaan LO DIY ialah untuk melaksanakan tugas-tugasnya yang antara lain:

a. Menyusun program kerja sesuai dengan fungsinya;

b. Menyebarluaskan pemahaman mengenai kedudukan, fungsi, tugas, dam wewenang dan program kerja yang dimiliki kepada seluruh masyarakat di daerah;

c. Melakukan koordinasi dan/atau kerja sama dengan berbagai lembaga, baik pemerintah maupun badan usaha, dalam rangka mendorong dan mewujudkan pemerintahan daerah yang bersih dan bebas dari korupsi, kolusi, nepotisme, penyalahgunaan wewenang, atau jabatan, tindakan sewenang-wenang dan penyimpangan usaha;

d. Menerima dan menindaklanjuti pengaduan dari masyarakat atas keputusan dan/atau tindakan penyelenggara pemerintahan daerah dan pengusaha dalam memberikan pelayanan kepada masyarakat yang dirasakan tidak adil, diskriminatif, tidak patut, merugikan atau bertentangan dengan hukum;

e. Menerima dan menindaklanjuti pengaduan dari masyarakat atas dugaan penyimpanan dalam penyelenggaraan pemerintahan daerah dan praktik dunia usaha;

f. Atas prakarsa sendiri melakukan tindak lanjut terhadap dugaan penyimpangan dalam penyelenggaraan pemerintahan daerah dan praktik dunia usaha, tetapi dalam pelaksanaannya harus prosedural dan sesuai dengan peraturan perundang-undangan;

g. Membangun jaringan kerja dalam upaya pencegahan penyimpangan dalam penyelenggaraan pemerintahan daerah dan praktik usaha;

h. Membuat penelitian dan review kebijakan atas persoalan-persoalan publik;

i. Membuat laporan triwulanan dan tahunan kepada Gubernur terhadap pelaksanaan tugas sesuai dengan ketentuan peraturan perundangundangan yang berlaku.

Untuk mendukung fungsi dan tugas tersebut, LO

DIY diberikan wewenang yaitu:

a. meminta keterangan secara lisan dan/atau tertulis kepada pihak pelapor, terlapor dan atau pihak lain yang terkait dengan pengaduan yang disampaikan kepad LO DIY;

b. melakukan klarifikasi terhadap pihak pelapor, terlapor dan/atau pihak lain yang terkait untuk mendapatkan kebenaran isi pengaduan;

c. meminta keterangan secara lisan dan/atau tertulis kepada pemerintah daerah berkaitan dengan adanya dugaan penyimpangan teerhadap asasasas pemerintahan daerah yang bersih dan bebas dari korupsi, kolusi, nepotisme, penyalahgunaan kekuasaan atau jabatan, dan tindakan sewenangwenang, sesuai dengan peraturan perundangundangan dengan tetap menjunjung tinggi asas praduga tak bersalah;

d. meminta keterangan secara lisan dan/atau tertulis kepada pengusaha berkaitan dengan adanya dugaan penyimpangan dalam praktik usaha;

e. membuat rekomendasi kepada pihak pelapor dan pihak terlapor dalam rangka penyelesaian masalah antara kedua belah pihak;

f. menyampaikan rekomendasi sebagaimana dimaksud pada huruf e kepada pihak pelapor dan terlapor serta pihak-pihak lain yang terkait dalam rangka memfasilitasi penyelesaian masalah;

g. menyampaikan tembusan rekomendasi sebagaimana dimaksud pada huruf e kepada Gubernur melalui Biro Hukum Setda DIY;

h. bila diperlukan dapat mengumumkan atau mempublikasikan hasil rekomendasi untuk diketahui masyarakat, sepanjang ada pesetujuan dari Pelapor, Terlapor, maupun Gubernur melalui Biro Hukum Sekretariat Daerah DIY.

Seperti yang telah dibahas sebelumnya bahwa LO DIY merupakan penggabungan dari Ombudsman Daerah DIY dan Ombudsman Swasta DIY. Kedua lembaga tersebut dibentuk pada tahun 2004 melalui Keputusan Gubernur DIY, sehingga keberadaan kedua lembaga daerah tersebut telah ada 4 (empat) tahun sebelum diundangkannya UU No. 37 Tahun 2008. Pasal 46 UU No. 37 Tahun 2008 pada pokoknya mengatur badan hukum, lembaga, institusi, terbitan atau lainnya yang menggunakan nama ombudsman namun bukan lembaga Ombudsman yang melaksanakan fungsi dan tugas berdasarkan UU No. 37 Tahun 2008 harus mengganti namanya dalam kurun waktu paling lama 2 (dua) tahun sejak undangundang tersebut mulai berlaku. Apabila ketentuan itu 
tidak dipatuhi, maka dianggap menggunakan nama "Ombudsman" secara tidak sah.

Ketentuan Pasal 46 UU No. 37 Tahun 2008 telah dinyatakan bertentangan dengan UUD NRI 1945 dan tidak mempunyai kekuatan hukum mengikat oleh Mahkamah Konstitusi melalui Putusannya Nomor 62/PUU-VIII/2010. Dalam putusan tersebut Mahkamah berpendapat yang pada intinya adalah:

- Istilah ombudsman tidak boleh dimonopoli oleh negara sebab dalam praktiknya masyarakat telah mengenal ombudsman sebagai lembaga independen yang menerima, menginvestigasi, dan ikut memberi alternatif penyelesaian atas pengaduan atau keluhan dari masyarakat. Fungsi ombudsman tersebut dibutuhkan oleh banyak pihak untuk banyak hal. Jika ada monopoli terkait penggunaan istilah ombudsman tentunya akan dapat mengganggu proses komunikasi publik dan kebebasan dalam menyampaikan suatu gagasan yang telah dijamin oleh konstitusi;

- Keberadaan lembaga ombudsman daerah yang dibentuk secara sah menurut hukum merupakan suatu hal yang penting dan harus dilindungi oleh hukum karena pembentukan ombudsman daerah oleh beberapa pemerintah daerah sebelum diundangkannya UU No. 37 Tahun 2008 merupakan wujud tindakan positif dari pemerintah daerah untuk menjamin penyelenggaraan pemerintahan yang akuntabel dan transparan, dengan memberikan ruang bagi masyarakat untuk menyampaikan laporan atas segala keluhan terkait pelayanan publik kepada lembaga ombudsman. Sehingga seharusnya Ombudsman Republik Indonesia tetap mengakui keberadaan lembaga-lembaga ombudsman daerah yang telah dibentuk oleh pemerintah daerah dan dipercayai oleh masyarakat;

- Larangan pembentukan lembaga dengan menggunakan istilah ombudsman sebagai nama oleh suatu organ atau lembaga selain Ombudsman Republik Indonesia bertentangan dengan semangat, perlindungan dan jaminan konstitusional meliputi hak untuk mendapat jaminan, perlindungan, pengakuan dan kepastian hukum yang adil serta perlakuan yang sama dihadapan hukum dalam pemerintahan serta hak untuk memajukan dirinya dalam memperjuangkan haknya secara kolektif untuk membangun masyarakat, bangsa, dan negaranya.

Sehingga berdasarkan uraian tersebut di atas yang dikaitkan dengan pembentukan serta pertanggungjawaban langsung LO DIY kepada Gubernur, menunjukan bahwa Lembaga Ombudsman merupakan lembaga pada pemerintah daerah. Independensi LO DIY adalah dalam rangka menjalankan tugas dan fungsinya dalam melakukan pengawasan penyelenggaraan pelayanan publik.

Untuk mempermudah pemahaman tentang kedudukan LO DIY dalam sistem pemerintahan daerah, dapat dilihat dari bagan di bawah ini:

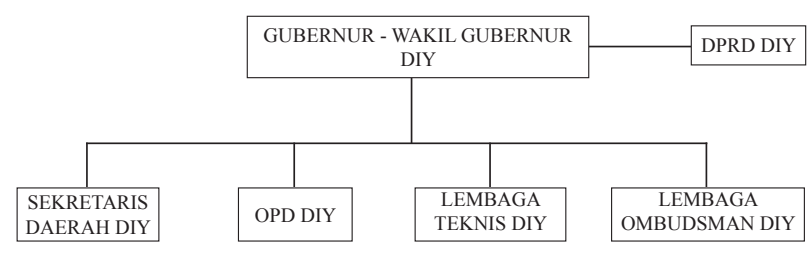

Oleh karena LO DIY merupakan lembaga pada Pemerintah Daerah maka sesuai ketentuan Pasal 351 ayat (1) UU No. 23 Tahun 2014 bahwa masyarakat mempunyai hak untuk melakukan pengaduan atas penyelenggaraan pelayanan publik salah satunya kepada Pemerintah Daerah. Dalam hal ini manakala pemerintah daerah telah memiliki ombudsman daerah maka pengaduan masyarakat terkait permasalahan penyelenggaraan pelayanan publik dapat disampaikan kepada Ombudsman Daerah. Selain Daerah Istimewa Yogyakarta, terdapat beberapa daerah lain yang telah memiliki Ombudsman Daerah seperti Kota Makassar dan Kabupaten Asahan. Berbeda dengan daerah-daerah yang telah memiliki ombudsman daerah, daerah lain yang belum atau tidak memiliki lembaga ombudsman daerah manakala menghadapi permasalahan mengenai penyelenggaraan pelayanan publik atau adanya dugaan maladministrasi maka masyarakat dapat menyampaikan pengaduan pada Ombudsman Republik Indonesia melalui perwakilan ombudsman di daerah.

Dengan berlakunya ketentuan Pasal 351 ayat (1) UU No. 23 Tahun 2014 dan adanya Putusan Mahkamah Konstitusi Nomor 62/PUU-VIII/2010 menjadi salah satu faktor adanya persandingan antara Lembaga Ombudsman Daerah dan Ombudsman Perwakilan di Daerah. Dimana dalam Pasal 351 ayat (1) UU No. 23 Tahun 2014 mengatur bahwa masyarakat berhak mengadukan penyelenggaraan 
pelayanan publik kepada Pemerintah Daerah, Ombudsman, dan/atau DPRD. Sedangkan dalam Putusan Mahkamah Konstitusi Nomor 62/ PUU-VIII/2010, mahkamah berpendapat bahwa keberadaan lembaga ombudsman daerah yang dibentuk secara sah menurut hukum merupakan suatu hal yang penting dan harus dilindungi oleh hukum. Sehingga terjadilah persandingan antara Lembaga Ombudsman Daerah dan Ombudsman Perwakilan di Daerah yang dapat digambarkan seperti bagan di bawah ini:

\section{Perbandingan Lembaga Ombudsman Republik Indonesia, Ombudsman di Daerah dan LO DIY}

Perbandingan antara Ombudsman Republik Indonesia, Ombudsman di Daerah dan LO DIY, akan diuraikan pada tabel persamaan dan tabel perbedaan di samping.

Mengenai pengawasan terhadap Ombudsman Republik Indonesia, tidak ada pengaturan yang tegas mengaturnya berbeda dengan pengawasan pada Ombudsman Perwakilan di Daerah dan LO DIY yang dengan tegas diatur. Pada pembahasan sebelumnya, disampaikan bahwa lembaga negara baru yang bersifat independen disebut sebagai lembaga negara penunjang (auxiliary institutions atau state auxiliary organ). Maka Ombudsman merupakan salah satu lembaga negara baru yang bersifat independen maka Ombudsman Republik Indonesia termasuk lembaga negara yang bersifat penunjang. Untuk itu berdasarkan Ratio decidendi Putusan MK No. 36/PUU-XV/2017 terkait independensi Komisi Pemberantasan Korupsi (KPK) sebagai lembaga negara penunjang, Mahkamah berpendapat bahwa independensi dan bebasnya KPK sebagai lembaga negara penunjang dari pengaruh kekuasaan mana pun adalah dalam melaksanakan tugas dan wewenang yang dimiliki. Dengan adanya putusan tersebut maka lembaga- lembaga penunjang yang bersifat independen seperti Ombudsman menjadi tidak mutlak. Karakteristik independen sebatas dalam melaksanakan tugas dan wewenang yang dimilikinya. Dengan melihat tujuan dibentuknya, proses dan pertanggungjawaban lembaga independen, kita dapat melihat berada di ranah manakah lembaga independen tersebut eksekutif, legislatif, atau yudisiil. Dan karenanya terhadap lembaga independen masih berlaku adanya paradigma checks and balances sebagai wujud dari pengawasan kekuasaan.

Berkaitan dengan pertanggungjawaban Ombudsman RI tidak diatur tegas dalam UU No. 37 Tahun 2008. Dalam penjelasan Pasal 42 ayat (1) UU No. 37 Tahun 2008 disebutkan bahwa laporan yang disampaikan Ombudsman kepadaDPR maupun Presiden bukanlah merupakan bentuk pertanggungjawaban. Namun dapat dijadikan bahan untuk mengambil kebijakan dalam membangun pelayanan publik yang lebih baik oleh DPR maupun Presiden.

Dalam proses dibentuknya atau pengangkatan keanggotaan Ombudsman Republik Indonesia campur tangan eksekutif dalam hal ini Presiden sangat kental. Dimana calon diusulkan dan diangkat oleh Presiden. Sedangkan DPR hanya ada pada tahan memilih keanggotaan berdasarkan calon yang telah diusulkan oleh Presiden.

Tujuan dibentuknya Ombudsman guna melakukan pengawasan penyelenggara pelayanan publik. Fokus pengawasan Ombudsman berbeda pengawasan oleh DPR. Pengawasan yang dilakukan DPR atau DPRD meliputi pengawasan politik dan administratif pada tataran pengaturan dan pelaksanaan kebijakan pemerintah. Sedangkan pengawasan yang dilakukan Ombudsman menyangkut perilaku aparat penyelenggara negara dalam rangka pelayanan

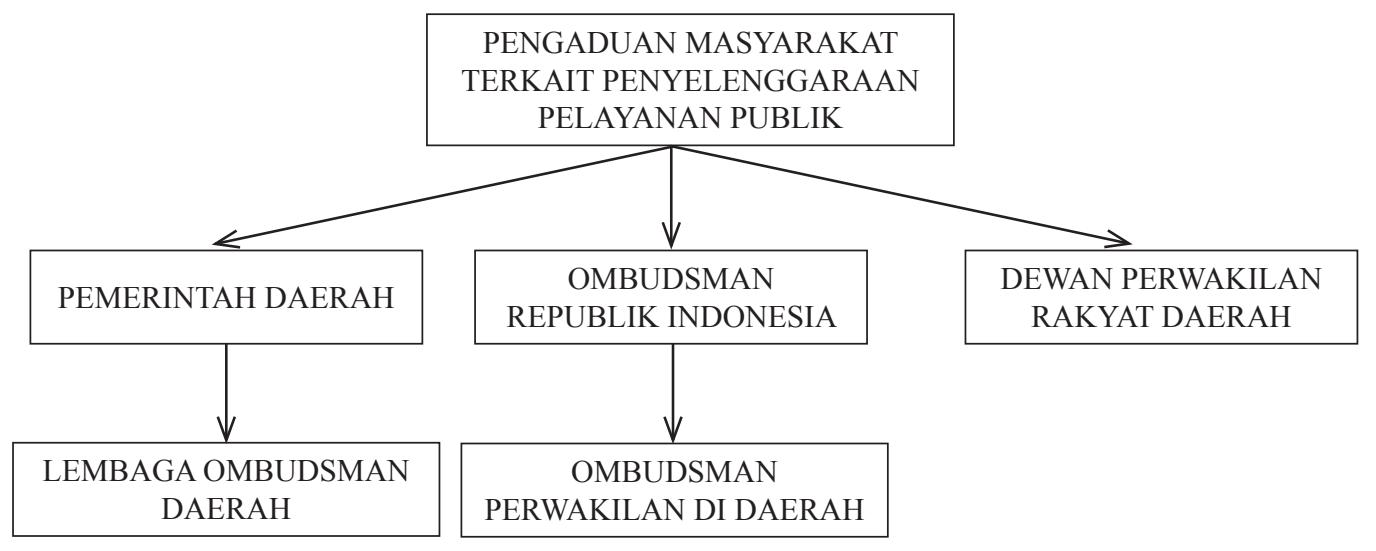




\begin{tabular}{|c|c|c|c|}
\hline PERSAMAAN & $\begin{array}{c}\text { OMBUDSMAN } \\
\text { REPUBLIK INDONESIA }\end{array}$ & $\begin{array}{l}\text { PERWAKILAN } \\
\text { OMBUDSMAN DI } \\
\text { DAERAH }\end{array}$ & $\begin{array}{l}\text { OMBUDSMAN DAERAH } \\
\text { ISTIMEWA YOGYAKARTA }\end{array}$ \\
\hline Fungsi & \multicolumn{3}{|c|}{ Pengawasan terhadap penyelenggaraan pelayanan publik } \\
\hline Tugas & \multicolumn{3}{|c|}{$\begin{array}{l}\text { a. Menerima dan menindaklanjuti pengaduan dari masyarakat atas dugaan maladministrasi dalam } \\
\text { penyelenggaraan pelayanan publik; } \\
\text { b. Melakukan koordinasi dan/atau kerja sama dengan berbagai lembaga; } \\
\text { c. Membangun jaringan kerja; } \\
\text { d. Melakukan upaya pencegahan maladministrasi; } \\
\text { e. Atas prakarsa sendiri melakukan investigasi terhadap dugaan maladministrasi dalam penyelenggaraan } \\
\text { pelayanan publik sesuai peraturan perundang-undangan yang berlaku. }\end{array}$} \\
\hline Wewenang & \multicolumn{3}{|c|}{$\begin{array}{l}\text { a. Meminta keterangan secara lisan dan/atau tertulis kepada pihak pelapor, terlapor dan atau pihak lain } \\
\text { yang terkait dengan pengaduan dugaan maladministrasi yang disampaikan; } \\
\text { b. Meminta klarifikasi pelapor, terlapor dan/atau pihak lain; } \\
\text { c. Membuat rekomendasi mengenai penyelesaian pengaduan; } \\
\text { d. Bila diperlukan (demi kepentingan umum) dapat mengumumkan atau mempublikasikan hasil } \\
\text { rekomendasi. }\end{array}$} \\
\hline Keluaran/Output & \multicolumn{3}{|l|}{ Berupa Rekomendasi } \\
\hline PERBEDAAN & $\begin{array}{c}\text { OMBUDSMAN } \\
\text { REPUBLIK INDONESIA }\end{array}$ & $\begin{array}{l}\text { PERWAKILAN } \\
\text { OMBUDSMAN DI } \\
\text { DAERAH } \\
\end{array}$ & $\begin{array}{l}\text { OMBUDSMAN DAERAH } \\
\text { ISTIMEWA YOGYAKARTA }\end{array}$ \\
\hline Yurisdiksi & Seluruh wilayah NKRI & $\begin{array}{l}\text { Kota, Kabupaten, atau } \\
\text { Provinsi }\end{array}$ & Daerah Istimewa Yogyakarta \\
\hline Kedudukan & Lembaga Negara Independen & $\begin{array}{l}\text { Perwakilan Lembaga Negara } \\
\text { Independen di Daerah }\end{array}$ & Lembaga Daerah Independen \\
\hline Dasar Pembentukan & Undang-Undang & Peraturan Pemerintah & Peraturan Gubernur DIY \\
\hline Fungsi & $\begin{array}{l}\text { Pengawasan terhadap penye } \\
\text { tidak hanya diselenggarakan ol } \\
\text { daerah tetapi juga yang diselen } \\
\text { BHMN serta badan swasta atau } \\
\text { menyelenggarakan pelayanan }\end{array}$ & $\begin{array}{l}\text { nggaraan pelayanan publik } \\
\text { h pemerintahan pusat maupun } \\
\text { garakan BUMN, BUMD, dan } \\
\text { erseorangan yang diberi tugas } \\
\text { blik tertentu. }\end{array}$ & $\begin{array}{l}\text { Tidak hanya pengawasan kepada } \\
\text { penyelenggaraan pelayanan publik } \\
\text { tetapi juga mediasi pada pemerintahan } \\
\text { daerah dan praktik dunia usaha. }\end{array}$ \\
\hline Tugas & $\begin{array}{l}\text { Selain tugas yang terdapat pada } \\
\text { lain yang berbeda dengan LO } \\
\text { a. melakukan pemeriksaan sub } \\
\text { b. melakukan tugas lain ya } \\
\text { perundang-undangan. }\end{array}$ & $\begin{array}{l}\text { abel persamaan, terdapat tugas } \\
\text { Y, yaitu: } \\
\text { tansi atas Laporan; } \\
\text { g diberikan oleh peraturan }\end{array}$ & $\begin{array}{l}\text { Selain tugas yang terdapat pada tabel } \\
\text { persamaan, terdapat tugas lain yang } \\
\text { berbeda dengan Ombudsman RI atau } \\
\text { Perwakilan Ombudsman di daerah, } \\
\text { yaitu: } \\
\text { a. Menyusun program kerja LO DIY } \\
\text { sesuai dengan fungsinya; } \\
\text { b. Menyebarluaskan pemahaman } \\
\text { mengenai kedudukan, fungsi, } \\
\text { tugas, dan wewenang dan program } \\
\text { kerja LO DIY kepada seluruh } \\
\text { masyarakat di daerah; } \\
\text { c. Pengaduan yang diterima dan } \\
\text { ditindaklanjuti tidak hanya tentang } \\
\text { dugaan maladministrasi tetapi } \\
\text { juga praktik dunia usaha selain itu } \\
\text { juga keputusan dan/atau tindakan } \\
\text { penyelenggara pemerintahan } \\
\text { daerah dan pengusaha dalam } \\
\text { memberikan pelayanan kepada } \\
\text { masyarakat yang dirasakan tidak } \\
\text { adil, dikriminatif, tidak patut, } \\
\text { merugikan atau bertentangan } \\
\text { dengan hukum; } \\
\text { d. Membuat penelitian dan review } \\
\text { kebijakan atas persoalan-persoalan } \\
\text { publik; }\end{array}$ \\
\hline
\end{tabular}




\begin{tabular}{cccc}
\hline \hline & & \\
\hline PERBEDAAN & OMBUDSMAN & PERWAKILAN & OMBUDSMAN DAERAH \\
& REPUBLIK INDONESIA & OMBUDSMAN DI & DAERAH \\
ISTIMEWA YOGYAKARTA
\end{tabular}

e. Membuat laporan triwulanan dan tahunan kepada Gubernur terhadap pelaksanaan tugas sesuai dengan ketentuan peraturan perundangundangan yang berlaku.

Wewenang
Selain wewenang yang terdapat pada tabel persamaan, terdapat
tugas lain yang berbeda dengan Lembaga Ombudsman DIY,
yaitu:
a. memeriksa keputusan, surat-menyurat, atau dokumen lain
yang ada pada Pelapor ataupun Terlapor untuk mendapatkan
kebenaran suatu Laporan;
b. meminta salinan atau fotokopi dokumen yang diperlukan dari
instansi mana pun untuk pemeriksaan Laporan dari instansi
Terlapor;
c. melakukan pemanggilan terhadap Pelapor, Terlapor, dan
pihak lain yang terkait dengan Laporan;
d. menyelesaikan laporan melalui mediasi dan konsiliasi atas
permintaan para pihak;
e. membuat Rekomendasi mengenai penyelesaian Laporan,
termasuk Rekomendasi untuk membayar ganti rugi dan/atau
rehabilitasi kepada pihak yang dirugikan;
f. menyampaikan saran kepada Presiden, kepala daerah, atau
pimpinan Penyelenggara Negara lainnya guna perbaikan
dan penyempurnaan organisasi dan/atau prosedur pelayanan
publik;
g. menyampaikan saran kepada DPR dan/atau Presiden, DPRD
dan/atau kepala daerah agar terhadap undang-undang dan
peraturan perundang-undangan lainnya diadakan perubahan
dalam rangka mencegah Maladministrasi.

Obyek Pengawasan Penyelenggaraan pelayanan publik oleh penyelenggara negara dan pemerintahan termasuk yang diselenggarakan oleh BUMN, BUMD, BHMN serta badan swasta atau perseorangan yang diberi tugas menyelenggarakan pelayanan publik tertentu yang sumber dananya berasal dari APBN dan/atau APBD untuk sebagian atau seluruhnya.

Keluaran/Output Rekomendasi yang dikeluarkan dapat berisi rekomendasi untuk membayar ganti rugi dan/atau rehabilitasi kepada pihak yang dirugikan.

Selain wewenang yang terdapat pada tabel persamaan, terdapat tugas lain yang berbeda dengan Ombudsman RI atau Perwakilan Ombudsman di daerah, yaitu:

a. meminta keterangan secara lisan dan/atau tertulis kepada pengusaha berkaitan dengan adanya dugaan penyimpangan dalam praktik usaha;

b. membuat rekomendasi kepada pihak pelapor dan pihak terlapor dalam rangka penyelesaian masalah antara kedua belah pihak;

c. menyampaikan rekomendasi kepada pihak pelapor dan terlapor serta pihak-pihak lain yang terkait dalam rangka memfasilitasi penyelesaian masalah;

d. menyampaikan tembusan rekomendasi kepada Gubernur melalui Biro Hukum Setda DIY.

Khususnya penyelenggaraan pelayanan publik yang dilakukan oleh pemerintahan daerah dan badan usaha.

Tidak diatur secara tegas apakah rekomendasi yang dikeluarkan Lembaga Ombudsman DIY dapat berisi rekomendasi untuk membayar ganti rugi dan/atau rehabilitasi kepada pihak yang dirugikan.

\begin{tabular}{|c|c|c|c|}
\hline Susunan Organisasi & $\begin{array}{l}\text { Unsur Anggota: } \\
\text { - } 1 \text { orang Ketua sekaligus } \\
\text { merangkap sebagai anggota. } \\
\text { - } 1 \text { orang Wakil Ketua } \\
\text { sekaligus merangkap sebagai } \\
\text { anggota. } \\
\text { - } 7 \text { orang anggota. } \\
\text { Unsur Penunjang: } \\
\text { - Asisten Ombudsman. } \\
\text { - Sekretariat yang dipimpin } \\
\text { oleh Sekretaris Jenderal. }\end{array}$ & $\begin{array}{l}\text { Unsur Perwakilan } \\
\text { Ombudsman: } \\
\text { - } 1 \text { orang Kepala Perwakilan } \\
\quad \text { Ombudsman; dan } \\
\text { - } \quad \text { asisten Ombudsman. } \\
\text { Unsur Penunjang: } \\
\text { PNS di lingkungan Sekretariat } \\
\text { Jenderal Ombudsman }\end{array}$ & $\begin{array}{l}\text { Unsur Anggota: } \\
\text { - Ketua sekaligus merangkap } \\
\text { sebagai anggota; } \\
\text { - Wakil ketua sekaligus merangkap } \\
\text { sebagai anggota bidang aparatur } \\
\text { pemerintah daerah; } \\
\text { - Wakil ketua yang merangkap } \\
\text { sebagai anggota bidang pembinaan } \\
\text { dan pengembangan usaha swasta; } \\
\text { - Wakil ketua yang merangkap } \\
\text { sebagai anggota bidang pelayanan } \\
\text { dan investigasi; } \\
\text { - Wakil ketua yang merangkap } \\
\text { sebagai anggota bidang sosialisasi, } \\
\text { kerja sama dan penguatan jaringan; }\end{array}$ \\
\hline
\end{tabular}




\begin{tabular}{|c|c|c|c|}
\hline PERBEDAAN & $\begin{array}{l}\text { OMBUDSMAN } \\
\text { REPUBLIK INDONESIA }\end{array}$ & $\begin{array}{l}\text { PERWAKILAN } \\
\text { OMBUDSMAN DI } \\
\text { DAERAH }\end{array}$ & $\begin{array}{l}\text { OMBUDSMAN DAERAH } \\
\text { ISTIMEWA YOGYAKARTA }\end{array}$ \\
\hline & & & $\begin{array}{l}\text { - Wakil ketua merangkap } \\
\text { anggota bidang penelitian dan } \\
\text { pengembangan serta hubungan } \\
\text { kelembagaan; } \\
\text { - Wakil ketua yang merangkap } \\
\text { anggota pada bidang monitoring } \\
\text { dan evaluasi. } \\
\text { Unsur Penunjang: } \\
\text { - Asisten-asisten } \\
\text { - Sekretariat }\end{array}$ \\
\hline $\begin{array}{l}\text { Pengangkatan } \\
\text { Keanggotaan }\end{array}$ & $\begin{array}{l}\text { Calon diusulkan oleh presiden, } \\
\text { dipilih oleh DPR dan diangkat } \\
\text { oleh Presiden. }\end{array}$ & $\begin{array}{l}\text { Kepala Perwakilan } \\
\text { Ombudsman dan Asisten } \\
\text { Ombudsman diangkat oleh } \\
\text { Ketua Ombudsman RI }\end{array}$ & $\begin{array}{l}\text { Ditetapkan dengan Keputusan } \\
\text { Gubernur DIY }\end{array}$ \\
\hline $\begin{array}{l}\text { Pengangkatan Unsur } \\
\text { Penunjang }\end{array}$ & $\begin{array}{l}\text { - Asisten Ombudsman } \\
\text { diangkat oleh Ketua } \\
\text { Ombudsman RI } \\
\text { - Sekretaris Jenderal diangkat } \\
\text { oleh Presiden }\end{array}$ & $\begin{array}{l}\text { Pengangkatan PNS di } \\
\text { lingkungan Sekretariat } \\
\text { Jenderal Ombudsman } \\
\text { dilakukan oleh Sekretaris } \\
\text { Jenderal Ombudsman }\end{array}$ & $\begin{array}{l}\text { Ditetapkan melalui Keputusan Ketua } \\
\text { LO DIY }\end{array}$ \\
\hline Pertanggungjawaban & Kepada Presiden dan DPR & $\begin{array}{l}\text { Kepada Ketua Ombudsman } \\
\text { RI }\end{array}$ & Kepada Gubernur DIY \\
\hline Pengawasan & DPR & Ombudsman RI & Inspektorat DIY atas nama Gubernur \\
\hline Sumber Keuangan & APBN & & $\begin{array}{ll}\text { - } & \text { APBD DIY } \\
\text { - } & \text { Sumber dana lainnya yang sah dan } \\
& \text { tidak mengikat. }\end{array}$ \\
\hline
\end{tabular}

publik. ${ }^{32}$ Sehingga tidak tepat jika Ombudsman ditempatkan pada lembaga independen di ranah legislatif.

Fokus pengawasan yang dilakukan Ombudsman menyerupai pengawasan yang dilakukan oleh Inspektorat. Yang membedakan hanyalah produk hukum yang dikeluarkan, ruang lingkup dan kedudukannya. Ruang lingkup inspektorat hanya terbatas pada Departemen atau Lembaga Pemerintah Non Departemen (saat ini menjadi Kementerian atau Lembaga Pemerintah Non Kementerian) dan keputusannya bersifat mengikat. Sedangkan Ombusman bersifat eksternal dan ruang lingkupnya meliputi semua institusi penyelenggara negara dan pemerintahan bahkan individu dan swasta. ${ }^{33}$ Keluaran Ombudsman berupa rekomendasi.

Berdasarkan hal-hal tersebut di atas, maka keberadaan Ombudsman Republik Indonesia sebagai lembaga independen lebih mengarah pada ranah eksekutif. Oleh karenanya, ombudsman tidak terlepas dari pengawasan yang dilakukan Dewan

\footnotetext{
${ }^{32}$ H.M. Galang Asmara. op.cit., h. 141.

${ }^{33}$ ibid.
}

Perwakilan Rakyat. Mengingat fungsi kontrol dan pengawasan melekat pada Dewan Perwakilan Rakyat terhadap eksekutif. Seperti yang telah disampaikan sebelumnya bahwa terhadap lembaga independen termasuk Ombudsman masih berlaku adanya paradigma checks and balances sebagai wujud dari pengawasan kekuasaan.

\section{Hubungan Antara Ombudsman Republik Indonesia dengan LO DIY}

Keberadaan LO DIY merupakan wujud pengakuan dan penghormatan negara terhadap kekhasan atau kekhususan Daerah Istimewa Yogyakarta. Selaras dengan hal tersebut dalam Pasal 43 ayat (1) UU No. 37 Tahun 2008 mengatur bahwa Ombudsman RI dapat mendirikan perwakilan Ombudsman di daerah baik kota, kabupaten atau provinsi apabila dipandang perlu. Dengan dilakukan penafsiran gramatikal pada ketentuan tersebut dapat kita simpulkan bahwa pendirian ombudsman perwakilan di daerah baik kota, kabupaten atau provinsi bukanlah hal yang wajib. Frasa "dapat" dalam ketentuan tersebut menunjukkan bahwa pendirian 
perwakilan Ombudsman di daerah merupakan suatu wewenang diskresi pada Ombudsman Republik Indonesia.

Diskresi adalah wewenang pemerintah untuk melakukan pilihan atas tindakan yang dilakukan. ${ }^{34}$ Diskresi atau wewenang bebas tidak diartikan sebagai suatu kekuasaan yang tidak terbatas, melainkan kekuasaan tersebut tetaplah harus tunduk kepada hukum. ${ }^{35}$ Untuk itu dalam hal Ombudsman Republik Indonesia merasa perlu untuk membentuk perwakilan ombudsman di daerah harus tunduk pada ketentuan dalam Peraturan Pemerintah Nomor 21 Tahun 2011.

Ada beberapa pertimbangan Ombudsman Republik Indonesia dalam membentuk perwakilan ombudsman di daerah seperti kebutuhan masyarakat, efektivitas, efisiensi, ketersediaan sumber daya, kompleksitas dan beban kerja. Selain itu, faktor kekhususan, keistimewaan serta kemandirian suatu daerah dalam rangka penyelenggaraan pemerintahan juga cukup penting untuk dijadikan bahan pertimbangan.

Keberadaan LO DIY wajib diakui dan dihormati oleh negara.Keberadaan Ombudsman DIY menunjukkan kemandirian dan inovasi daerah. Baik LO DIY DIY maupun Ombudsman Republik Indonesia memiliki beberapa fungsi, tugas dan wewenang yang samasebagaimana tertuang pada tabel persamaan. Hal tersebut menunjukan bahwa antara LO DIY dengan Ombudsman Republik Indonesia atau Ombudsman Perwakilan di Daerah memiliki hubungan fungsional dalam menjalankan fungsi pengawasan penyelenggaraan pelayanan publik oleh penyelenggara pelayanan publik dalam memberikan layanan. Hal ini berbeda dengan Perwakilan Ombudsman di Daerah dengan Ombudsman Republik Indonesia yang hubungannya struktural hierarki.

Hubungan fungsional antara LO DIY dengan Ombudsman Perwakilan di Daerah sepatutnya dimanfaatkan oleh kedua lembaga tersebut untuk saling bersinergi. Dari tabel perbandingan yang telah diuraikan di atas, dapat kita ketahui bahwa antara

\footnotetext{
34 Tatiek Sri Djatmiati. (2020). Diskresi dalam konteks Undang-Undang Nomor 30 Tahun 2014 tentang Administrasi Pemerintahan, dalam Hukum Administrasi Sebuah Bunga Rampai. Yogyakarta: LaksBang Justitia, h. 130. (selanjutnya disingkat Tatiek Sri Djatmiati III).

35 Philipus M. Hadjon. (1993). Pemerintahan Menurut Hukum (Wet-en Rechtmatig Bestuur). Surabaya: Yuridika, h. 4.
}

kedua lembaga tersebut memiliki kekurangan maupun kelebihan tersendiri. Salah satu keunggulan LO DIY adalah tidak seperti ombudsman perwakilan di daerah sebagai wakil dari Ombudsman Republik Indonesia lebih menekankan pada pengawasan dan pengaduan terkain pelaksanaan pelayanan publik, LO DIY juga menekankan pada praktik dunia usaha. Juga terdapat kekurangan dalam pengaturan wewenang LO DIY, dimana wewenang mengeluarkan rekomendasi pada LO DIY tidak diatur lebih lanjut apakah rekomendasi tersebut dapat berisi rekomendasi untuk membayar ganti rugi dan/atau rehabilitasi kepada pihak yang dirugikan. Sedangkan ombudsman perwakilan di daerah sebagai wakil dari Ombudsman Republik Indonesia memiliki wewenang yang secara tegas diatur yaitu rekomendasi yang dikeluarkan dapat berisi rekomendasi untuk membayar ganti rugi dan/ atau rehabilitasi kepada pihak yang dirugikan.

Dari adanya kekurangan dan kelebihan dari LO DIY dan Ombudsman Perwakilan di Daerah tersebut serta adanya hubungan fungsional di antara keduanya, maka ada baiknya untuk kedua lembaga tersebut saling bersinergi. Jika suatu daerah telah memiliki lembaga ombudsman daerah yang wewenangnya paling sedikit sama dengan ombudsman perwakilan di daerah atau bahkan lebih luas wewenangnya, Ombudsman Republik Indonesia sebaiknya menggunakan anggaran yang dimiliki untuk difokuskan pada daerah-daerah yang belum memiliki lembaga ombudsman daerah.

\section{PENUTUP}

\section{Kesimpulan}

Berdasarkan pemaparan yang telah diuraikan di atas, maka dapat ditarik kesimpulan sebagai berikut:

Kedudukan Ombudsman Daerah Istimewa Yogyakarta dalam sistem pemerintahan daerah merupakan lembaga daerah independen. LO DIY berada di bawah Pemerintah Daerah karena dibentuk dan pertanggungjawabannya langsung kepada Gubernur. Keberlakuan Pasal 351 ayat (1) UndangUndang Nomor 23 Tahun 2014 tentang Pemerintahan Daerah serta Putusan Mahkamah Konstitusi Nomor berimplikasi pada adanya persandingan antara Lembaga Ombudsman Daerah sebagai lembaga independen daerah dan Ombudsman Perwakilan di Daerah sebagai wakil dari Ombudsman Republik Indonesia. 
2. Berdasarkan persamaan beberapa fungsi, tugas dan wewenang antara LO DIY dengan Ombudsman Perwakilan di Daerah menunjukan bahwa antara kedua lembaga tersebut memiliki hubungan fungsional. Merujuk pada perbandingan yang dilakukan dapat diketahui bahwa antara kedua lembaga tersebut terselip kekurangan dan kelebihan masing-masing sehingga ada baiknya jika kedua lembaga tersebut saling bersinergi dalam memberikan pelayanan kepada masyarakat. Apabila di kemudian hari wewenang yang dimiliki Lembaga Ombudsman daerah paling sedikit sama dengan ombudsman perwakilan daerah atau bahkan lebih luas, maka Ombudsman Republik Indonesia dapat memfokuskan anggaran yang dimiliki untuk daerah-daerah yang belum memiliki lembaga ombudsman daerah.

\section{Rekomendasi}

Bagi Pemerintah Daerah yang telah memiliki lembaga ombudsman daerah atau yang sejenisnya dengan menggunakan nama lain sebaiknya tidak perlu membubarkan lembaga yang telah ada tersebut, sebab keberadaan lembaga ombudsman daerah tetap diperlukan demi percepatan pelayanan pengaduan masyarakat atas adanya dugaan maladministrasi pada penyelenggaraan pelayanan publik. Seyogyanya kewenangan lembaga ombudsman daerah minimal sama dengan ombudsman perwakilan di daerah atau lebih diperluas sehingga pendirian lembaga ombudsman daerah sebagai wujud kemandirian dan inovasi daerah semakin terlihat nyata serta anggaran Ombudsman Republik Indonesia dapat difokuskan kepada daerah-daerah yang belum memiliki lembaga ombudsman daerah.

Bagi masyarakat yang di daerahnya telah ada lembaga ombudsman daerah atau yang sejenisnya dengan menggunakan nama lain sebaiknya dapat mengadukan dugaan maladministrasi penyelenggaraan pelayanan publik kepada lembaga ombudsman daerah. Namun jika kewenangan yang dimiliki lembaga ombudsman daerah masih dianggap kurang untuk menangani pengaduan dugaan maladministrasi yang sedang dihadapi maka dapat melakukan pengaduan ke Ombudsman Republik Indonesia melalui ombudsman perwakilan di daerah.
Bagi Ombudsman Daerah dan Ombudsman Perwakilan di Dearah, oleh karena keduanya memiliki beberapa kesamaan fungsi, tugas dan wewenang maka ada baiknya untuk saling bersinergi dalam menangani pengaduan masyarakat atas dugaan maladministrasi dalam penyelenggaraan pelayanan publik.

Bagi akademisi dapat melakukan penelitian lanjutan untuk mengetahui efektivitas lembaga ombudsman daerah dan ombudsman perwakilan di daerah sebagai bahan masukan bagi kedua lembaga tersebut untuk meningkatkan kinerja pelayanannya.

\section{DAFTAR PUSTAKA}

\section{Peraturan Perundang-undangan:}

Undang-Undang Dasar Negara Republik Indonesia Tahun 1945.

Undang-Undang Nomor 3 Tahun 1950 tentang Pembentukan Daerah Istimewa Jogjakarta (Berita Negara Republik Indonesia Tahun 1950 Nomor 3).

Undang-Undang Nomor 19 Tahun 1950 tentang Perubahan Dalam Undang-Undang Nomor 3 Tahun 1950 tentang Pembentukan Daerah Istimewa Jogjakarta (Berita Negara Republik Indonesia Tahun 1950 Nomor 48).

Undang-Undang Nomor 9 Tahun 1955 tentang Pengubahan Undang-Undang No. 3 jo. No. 19 Tahun 1950 tentang Pembentukan Daerah Istimewa Yogyakarta (Lembaran Negara Nomor 43 Tahun 1955, Tambahan Lembaran Negara Nomor 827 Tahun 1955).

Undang-Undang Nomor 37 Tahun 2008 tentang Ombudsman Republik Indonesia (Lembaran Negara Republik Indonesia Tahun 2008 Nomor 139, Tambahan Lembaran Negara Republik Indonesia Nomor 4899).

Undang-Undang Nomor 13 Tahun 2012 tentang Keistimewaan Daerah Istimewa Yogyakarta (Lembaran Negara Republik Indonesia Tahun 2012 Nomor 170, Tambahan Lembaran Negara Republik Indonesia Nomor 5339).

Undang-Undang Nomor 23 Tahun 2014 tentang Pemerintahan Daerah (Lembaran Negara Republik Indonesia Tahun 2014 Nomor 244, Tambahan Lembaran Negara Republik Indonesia Nomor 5587). 
Peraturan Pemerintah Nomor 21 Tahun 2011 tentang Pembentukan, Susunan, dan Tata Kerja Perwakilan Ombudsman Republik Indonesia di Daerah (Lembaran Negara Republik Indonesia Tahun 2011 Nomor 42, Tambahan Lembaran Negara Republik Indonesia Nomor 5207).

Peraturan Pemerintah Nomor 48 Tahun 2017 tentang Perubahan Atas Peraturan Pemerintah Nomor 48 Tahun 2017 Pembentukan, Susunan, dan Tata Kerja Perwakilan Ombudsman Republik Indonesia di Daerah (Lembaran Negara Republik Indonesia Tahun 2017 Nomor 246, Tambahan Lembaran Negara Republik Indonesia Nomor 6143).

\section{Putusan:}

Putusan Mahkamah Konstitusi Nomor 62/PUUVIII/2010 tanggal 23 Agustus 2012.

Putusan Mahkamah Konstitusi Nomor 36/PUUXV/2017 tanggal 8 Februari 2018.

\section{Buku:}

Gunawan A. Tauda. (2012). Komisi Negara Independen. Yogyakarta: Genta Press.

H.M. Galang Asmara. (2016). Hukum Kelembagaan Negara: Kedudukan Ombudsman Dalam Sistem Ketatanegaraan Republik Indonesia. Yogyakarta: LaksBang PRESSindo.

Jimly Asshiddiqie. (2013). Pengantar Ilmu Hukum Tata Negara. Jakarta: Rajawali Pers.

. (2016). Perkembangan \& Konsolidasi

Lembaga Negara Pasca Reformasi. Jakarta: Sinar Grafika.

(2017). Konstitusi \& Konstitusionalisme Indonesia. Jakarta: Sinar Grafika.

Maria Farida Indrati S. (2016). Ilmu Peraturan Perundang-Undangan 2 Proses dan Teknik Pembentukannya. Yogyakarta: Kanisius.

Nuryanto A. Daim. (2014). Hukum Administrasi Perbandingan Penyelesaian Maladministrasi oleh Ombudsman dan Pengadilan Tata Usaha Negara. Surabaya: LaksBang Justitia.

Peter Mahmud Marzuki. (2016). Penelitian Hukum. Jakarta: Prenadamedia Group.

Philipus M. Hadjon, et.al. (2015). Pengantar Hukum Administrasi Indonesia. Yogyakarta: Gadjah Mada University Press.
Philipus M. Hadjon. (1987). Perlindungan Hukum Bagi Rakyat di Indonesia. Surabaya: Bina Ilmu. . (1993). Pemerintahan Menurut Hukum (Wet-en Rechtmatig Bestuur). Surabaya: Yuridika.

Sri Winarsi dan Wilda Prihatiningtyas. (2019). Buku Ajar Pemerintahan Daerah. Surabaya: Airlangga University Press.

Sri Winarsi. (2018). Kedudukan Badan Pertanahan Nasional di Era Otonomi Daerah. Surabaya: Airlangga University Press.

Tatiek Sri Djatmiati. (2010). Maladministrasi Dalam Konteks Kesalahan Pribadi dan Kesalahan Jabatan, Tanggung Jawab Pribadi dan Tanggung Jawab Jabatan, dalam Philipus M. Hadjon, et.al. Hukum Administrasi dan Good Governance. Jakarta: Penerbit Universitas Trisakti.

. (2020). Diskresi dalam konteks UndangUndang Nomor 30 Tahun 2014 tentang Administrasi Pemerintahan, dalam Hukum Administrasi Sebuah Bunga Rampai. Yogyakarta: LaksBang Justitia.

. (2020). Faute Personelle dan Faute De Service Dalam Tanggung Gugat Negara, dalam Hukum Administrasi Sebuah Bunga Rampai. Yogyakarta: LaksBang Justitia.

Zainal Arifin Mochtar. (2019). Lembaga Negara Independen. Depok: Rajawali Pers.

\section{Jurnal:}

Muh. Hasrul. "Penataan Hubungan Kelembagaan Antara Pemerintah Provinsi dengan Pemerintah Kabupaten/Kota”. Jurnal PERSPEKTIF. Fakultas Hukum Universitas Wijaya Kusuma Surabaya, Vol. 22 No. 1 Tahun 2017 Edisi Januari.

\section{Tesis:}

Dhenok Panuntun Trisuci Asmawati. (2015). "Kedudukan Lembaga Ombudsman Daerah Istimewa Yogyakarta Pasca Undang-Undang Nomor 23 Tahun 2014 tentang Pemerintahan Daerah". Thesis. Fakultas Hukum Universitas Islam Indonesia. doi: https://dspace.uii. ac.id/bitstream/handle/123456789/8995/ TESIS_Dhenok\%20P.T.A_11912665. pdf? sequence $=1 \&$ isAllowed $=\mathrm{y}$ 